\title{
Partnership of University and Schools Within the Preparation of Future Teachers
}

\author{
https://doi.org/10.3991/ijet.v14i17.10829 \\ Olga V. Galustyan ${ }^{(\varpi)}$, Vladimir A. Kirik \\ Southern Federal University, Rostov-on-Don, Russia \\ olga.galustyan@gmail.com \\ Nataša Mazáčová \\ Charles University, Prague, Czech Republic
}

\begin{abstract}
The article analyzes partnership of university and schools within the preparation of future teachers. It deals with preparation of future teacher in order to master the project competence which is necessary for the implementation of future professional activities. The authors identify organizational, procedural, communicative, reflective components within the structure of project competence. The authors conclude that an important role plays organizing partnerships within the project activities during pedagogical practice of university students at schools.
\end{abstract}

Keywords-Partnership, university, school, project activities, cluster interaction, mentoring, higher education

\section{Introduction}

Modern educational process at university is subject to constant changes not only in connection with the new social, economic and political conditions, but also with the high rates of information and communication technologies that affect the change in the traditional model of the educational system, teaching and learning methods, and the need to design digital environment of educational content and organization of blended learning at educational institutions [2, 3, 17]. All these implies the readiness of future teacher to master the complex of competencies which are necessary for the implementation of future professional activities. consider that an important role within the process of preparation of future teachers is played by career guidance, which is expressed in the partnership interaction between university and schools as a part of training of future teachers. Cooperation of universities and schools within the preparation of future teachers is relevant and it contributes to the synergy of different levels of education.

The objectives of the partnership of the university and the school within the preparation of future teachers are the following: 
- Organization of pedagogical practice of university students at schools

- Implementation of career guidance projects

- Attracting of schoolchildren to creative, educational, design, research, search, and inventive activities under the guidance of scientists, mater students, administration of scientific institutions, school teachers, lectures of additional educational courses and other specialists within the educational field [18, 22, 23].

The problems of interaction between the universities and schools include the fact that there is no holistic concept of practical training of students for project activities in the modern school system in case of a request for the organization and development of project activities of students, both from the students themselves and from the teaching staff of educational organizations.

The main methods of organizing partnerships between university and schools within the preparation of future teachers will be accompanied by the representatives of higher schools in the development of project activities of university students, based on the demands of the technological, scientific, social, economic and cultural development of the country. It is also important to provide methodological assistance to the theoretical component in the development of projects in the form of lectures and master classes, as well as it is necessary to develop criteria for evaluating the results of students' project activities $[4,5]$.

The main goal of activity of pedagogical educational institutions is integration of education and science in a single educational, scientific and pedagogical complex which is designed to combine to efforts of educators in working-out programs for the up growth of university and school educational systems, creating innovations, bases and trainee sites for continuous teaching practice for students development of pedagogical science and the development of "breakthrough" educational technologies for universities and schools.

\section{Methodology}

$[24,25]$ Consider that project activities are required at every level of study within the modern educational practice. In addition, it should be noted that project activity has a specific orientation depending on the chosen specific nature of vocational training at higher educational institutions and schools which are relevant. Moreover, project activity contributes to synergies between different levels of education.

We consider the concept "educational project" as a form of work which is focused on the practical learning of an educational theme or educational section. Educational project is aimed at joint educational, cognitive, research, creative and play activities of students participating in a project group which has a common goal, methods and ways of working. The main goal of project activity is to achieve a common result in solving of a specific problem.

All participants of project activity acquire the necessary knowledge using various sources of information independently. They develop no only communicative skills while working in various groups, but also system of thinking forming a holistic view of phenomena and objects. 
It is expected to achieve the following results within realizing project activity:

- To prepare a teacher as carrier of culture and elite pedagogical education with a new pedagogical philosophy, possessing modern competencies, personal culture, who is able to work in the innovation mode, has a civil position and understands the degree of social responsibility for the development, training and education of the younger generation.

- To develop a region-oriented system for training teachers, based on social partnership of educational organizations.

- To form a corporate network of scientific, educational, innovative, training centers, creative laboratories, scientific schools.

- To implement a system of vocational guidance work with schoolchildren, providing an influx of applicants motivated for teaching activities [12, 14, 21$]$.

The concept "partnership" is defined as an effective tool that promotes economic development and increases competitiveness. Partnership interaction within the educational system provides a lot of opportunities for various partners of cluster. The basic principles of the functioning of partnership are:

- Geographical affiliation (possibility of building a spatial educational cluster within the region)

- Horizontal linearity (several departments, sectors, plots can be included in a larger cluster, for example, clusters are organized at the department level and they are included into the university innovation educational cluster)

- Vertical linearity (there is a common center for regulation and management of activities, center for planning and organizing cluster interaction processes, that means formation of cluster as a result of innovative integration of different levels of education with the management apparatus)

- Economic efficiency (different departments are united in cluster which provides economies of scale)

- Technological progressiveness (possibility of attracting applicants to the specialties of pedagogical field)

- Focused orientation (partnership and collaboration include various forms and levels of education which are centered around a single center which is a higher educational institution)

- High effectiveness (system of organizing of various kinds of scientific and practical events for all the participants is functioning continuously) $[1,6,9]$

\section{$3 \quad$ Materials and Methods}

The aim of partnership is formation of a consortium of universities and schools for organization, support and practical implementation of project activities of university students and schoolchildren.

The main methods of organizing partnerships within the project activity is accompany the process of developing options for representatives of schools when school- 
children choose topics for their projects based on the technological, scientific, social, economic and cultural development of the country. University provides methodologi$\mathrm{cal}$ assistance concerning theoretical component in developing projects in the forms of lectures and master classes, it also provides development of criteria for evaluating the results of project activities. It is necessary to attract university students as curators and project mentors in order to support practical part of the project implementation of schoolchildren. Students can be involved in project activities when they obtain competencies in the organization of project activities $[11,15,16]$.

The results of partnership are the practical implementation of schoolchildren's information, creative, social, educational or volunteer projects.

University organizes scientific and practical partner interaction activities on the possibilities of various types of cluster interaction acting as a mentor and a tutor. Thus, lectures and master classes serve as information components, principles and techniques. Conducting lectures and master classes should be entrusted by the university departments according to their specific scientific interests. The criteria for evaluating school projects may include assessment of the relevance and practical orientation, approaches and completeness of project development; validity of the proposed solutions, conclusions; quality of design, compliance with the standard requirements; answers to the questions during the presentation of the project; validation; completeness of revealing the topic and strengths of the work [7, 13,20].

One of the most important components of the project activities of schoolchildren is reflection. Reflection serves as a result of schoolchildren's activities and a motivational component towards the creation of their future projects. It is also important to get feedback from all the participants of the project. The most important questions of discussion are the following:

- Availability and assimilating of material concerning organization and planning of project activities

- Effectiveness and efficiency of using information by the project participants due to the retrieval skills

- Organization of the practical part of project activity;

- Difficulties which the participants of the project faced within the processing the results, etc. $[8,10,19]$

\section{$4 \quad$ Results}

Experimental work took place in 2017-2018 at Southern Federal University, Rostov-on-Don, Russia and 4 secondary schools of Rostov-on-Don, Russia. Students of Southern Federal University of specialty "Pedagogical education" participated in the experimental work. They had pedagogical practice at secondary schools. During the pedagogical practice we formed 2 groups (control group included 73 students and experimental group consisted of 72 students). Students of the control group had pedagogical practice according to the traditional curriculum. They got acquainted with the educational organization and the class where they had practice; observed individual schoolchildren; conducted observation diaries; conducted lessons; analyzed the les- 
sons of schoolteachers and students; carried out the preparation and conducted of extracurricular activities; analyzed pedagogical practice and wrote a report concerning teaching practice as a whole. Students of the experimental group also performed all the tasks mentioned above. In addition, students carried out organization and implementation of project activities by schoolchildren on such topics as "School environment", "Digital school", "Future parents", "Professional success", "Teacher of the future", "Volunteering and mentoring", etc. within the course of pedagogical practice. 4-5 schoolchildren took part in the implementation of each project, university students served as a tutors and mentors. 26 projects on different topics were prepared during the experimental work. The purpose of the project activities was development and execution of original practical-oriented tasks.

Tasks of project activities were the following:

- Practical mastery of the content and technology of organization of project and research activities in the field of education by schoolchildren participating in it.

- Design of educational situations (cases) of research, innovation and educational orientation, adequate to the level and nature of specialized training.

- Formation of groups of schoolchildren focused on the pedagogical profile and subsequent admission to educational institutions of psychological and pedagogical orientation.

The content of the project work consisted of several components:

- Introductory module was designed to acquaint schoolchildren with the principles and techniques of organizing project activities and assessing the quality of projects.

- Project module (participants of the project activities carried out project tasks under the guidance of students-tutors).

- Consultative module (students-tutors took part in weekly meetings with schoolchildren and discussed intermediate results of assignments, encountered difficulties and prospects for the future activities).

- Independent work (schoolchildren updated project tasks which were discussed at meetings with students-tutors every week).

- Psychological and pedagogical support of project participants (it included individual counseling, training, individual consultation of schoolchildren).

- Presentation of the projects (schoolchildren presented their projects (portfolio) at the final session under the guidance of students-tutors). School team leaders prepared written reports and recommendations with the analysis of the effectiveness and suggestions for improving the project implementation mechanism according to the results of the project activities.

Initial study was conducted to identify the initial level of project competence in the experimental and control groups at the beginning of experimental work. Project competence is determined by the level of students' readiness for the project activities, his / her individual design skills, and it is motivated by the desire for self-education. We have identified organizational, procedural, communicative, reflective components within the structure of project competence. Organizational component includes the 
ability to determine features, structure, nature, functions of the project activity. Procedural component means willingness and ability to apply forms, methods and tools rationally that contributes to the formation and the development of the project culture of future teacher. Communicative component is aimed at improving communicative skills, quality of independent work and various forms of interaction between the project participants. Reflective component includes the ability to highlight contradictions and difficulties in project activities, the ability to carry out project expertise. The data obtained were summarized and converted to percentage. The empirical data were quantitatively processed and analyzed at a qualitative level. Dynamics of step-by-step development of project competence was established and the obtained data revealed in Table 1 and Table 2 .

Table 1. The results of the assessment of the level of project competence in the experimental and control groups before the experimental work

\begin{tabular}{|l|c|c|c|c|c|c|}
\hline \multirow{2}{*}{$\begin{array}{c}\text { Project } \\
\text { competence }\end{array}$} & \multicolumn{3}{c|}{ Experimental group } & \multicolumn{3}{c|}{ Control group } \\
\cline { 2 - 7 } & $\begin{array}{c}\text { Low level, } \\
\text { \% }\end{array}$ & $\begin{array}{c}\text { Middle } \\
\text { level, \% }\end{array}$ & $\begin{array}{c}\text { High level, } \\
\text { \% }\end{array}$ & $\begin{array}{c}\text { Low level, } \\
\text { \% }\end{array}$ & $\begin{array}{c}\text { Middle } \\
\text { level, \% }\end{array}$ & $\begin{array}{c}\text { High level, } \\
\text { \% }\end{array}$ \\
\hline Organizational component & 44,8 & 33,3 & 21,9 & 48,6 & 36,4 & 15,0 \\
\hline Procedural component & 48,4 & 32,7 & 18,9 & 55,9 & 30,1 & 14,0 \\
\hline Communicative component & 46,5 & 36,4 & 17,1 & 51,7 & 33,6 & 14,7 \\
\hline Reflective component & 56,1 & 28,3 & 15,6 & 57,8 & 32,1 & 10,1 \\
\hline
\end{tabular}

Table 2. The results of the assessment of the level of project competence in the experimental and control groups after the experimental work

\begin{tabular}{|l|c|c|c|c|c|c|}
\hline \multirow{2}{*}{\multicolumn{1}{c|}{$\begin{array}{c}\text { Project } \\
\text { competence }\end{array}$}} & \multicolumn{3}{c|}{ Experimental group } & \multicolumn{3}{c|}{ Control group } \\
\cline { 2 - 7 } & $\begin{array}{c}\text { Low level, } \\
\text { \% }\end{array}$ & $\begin{array}{c}\text { Middle } \\
\text { level, \% }\end{array}$ & $\begin{array}{c}\text { High level, } \\
\text { \% }\end{array}$ & $\begin{array}{c}\text { Low level, } \\
\text { \% }\end{array}$ & $\begin{array}{c}\text { Middle } \\
\text { level, \% }\end{array}$ & $\begin{array}{c}\text { High level, } \\
\text { \% }\end{array}$ \\
\hline Organizational component & 19,6 & 39,6 & 40,8 & 43,8 & 36,1 & 20,1 \\
\hline Procedural component & 28,6 & 36,7 & 34,7 & 44,1 & 35,3 & 20,6 \\
\hline Communicative component & 22,3 & 38,7 & 39,0 & 47,4 & 36,1 & 16,5 \\
\hline Reflective component & 30,8 & 37,7 & 31,5 & 53,6 & 27,2 & 19,2 \\
\hline
\end{tabular}

Comparative analysis of the results of input and final diagnostics of the formation of project competence of students in the control and experimental groups showed a significant dynamic of the development of project competence in experimental groups, which indicates the effectiveness of the experimental work.

\section{Conclusion}

Organization of project activities at schools is not possible without a high-quality support of university which provides methodological and organizational support, helps to determine achievable goals and objectives of the project implementation, accompanies the development of skills for analyzing, understanding and reflecting the results of project activities. 
Universities can assume the role of mentor for project activities of students who have pedagogical practice and schoolchildren; focus on the development and implementation of a cluster interaction model within the framework of partnerships.

\section{Acknowledgement}

This publication was supported by Southern Federal University, Rostov-on-Don, Russia.

\section{$7 \quad$ References}

[1] Allen, J. M., Howells, K., \& Radford, R. (2013). A 'partnership in teaching excellence': Ways in which one school-university partnership has fostered teacher development. AsiaPacific Journal of Teacher Education, 41(1), 99-110. https://doi.org/10.1080/1359866x. 2012.753988

[2] Galustyan, O.V. Berezhnaya, I.F., \& Beloshitsky, A.V. (2017). Professional and Career Development of Teachers. Sodobna Pedagogika / Journal of Contemporary Educational Studies, 68(№4), pp.158-172. Retrieved from http://www.sodobna-pedagogika.net/wpcontent/uploads/2017/12/8-galustyan ang-2017-4.pdf https://doi.org/10.18411/a-2017-023

[3] Galustyan O.V., Gaidar K. M., Aleshina S. A., Ksenofontova A. N., Ledeneva A. V. (2018). Development of Group Subjectivity of Pupils within Collaborative Activities.TEM Journal. 7(4), 854-858.

[4] Galustyan, O. V., Lazukin, V. F., Petelin, A. S., \& Ostapenko, V. S. (2018). Diagnostic Activity of Teachers at High School. Revista Espacios, Vol. 39(N 10). Retrieved from http http://www.revistaespacios.com/a18v39n10/18391024.html

[5] Galustyan, O.V. (2017). Some Methodological Aspects of the Evaluation of Students' Educational Achievements at University. (IJCRSEE) International Journal of Cognitive Research in Science, Engineering and Education, 5(1), 43-48. Retrieved from http://www. ijcrsee.com/index.php/IJCRSEE/article/view/7/9 https://doi.org/10.5937/ijcrsee1701043g

[6] Damore, S. J., Kapustka, K. M., \& McDevitt, P. (2011). The urban professional development school network: Assessing the partnership's impact on initial teacher education. Teacher Educator, 46(3), 182-207. https://doi.org/10.1080/08878730.2011.582929

[7] Demakova, I. D., \& Klochkova, L. I. (2018). Innovative pedagogical designing as a resource for the development of the upbringing system of schoolchildren. Astra Salvensis, 6, 272-287.

[8] Drovosekov, S. E., \& Sakhieva, R. G. (2018). Peculiarities of using projects in learning English as a foreign language. XLinguae, 11(1), 91-101. https://doi.org/10.18355/xl.2018.1 $\underline{1.01 .09}$

[9] Epstein, J. L., \& Sanders, M. G. (2006). Prospects for change: Preparing educators for school, family, and community partnerships. Peabody Journal of Education, 81(2), 81-120. https://doi.org/10.1207/s15327930pje8102 5

[10] Finkelstein, N., Turpen, C., Pollock, S., Dubson, M., Iona, S., Keller, C., \& Otero, V. (2006). Evaluating a model of research-based practices for teacher preparation in a physics department: Colorado PhysTEC. Paper presented at the AIP Conference Proceedings, 818 3-6. https://doi.org/10.1063/1.2177009

[11] Francom, G. M., \& Moon, A. L. (2018). Enhancing educational technology confidence among teacher candidates: Benefits of and lessons learned from A 1:1 device university- 
elementary school partnership. Journal of Information Technology Education: Research, 17, 423-440. https://doi.org/10.28945/4129

[12] Fredriksen, P. M., Hjelle, O. P., Mamen, A., Meza, T. J., \& Westerberg, A. C. (2017). The health oriented pedagogical project (HOPP)- a controlled longitudinal school-based physical activity intervention program. BMC Public Health, 17(1) https://doi.org/10.1186/s12 $\underline{889-017-4282-Z}$

[13] Georgievna, K. A., Alekseevna, K. G., \& Zhabagievich, N. A. (2018). Pre-university training: Aims, problems, principles. Perspektivy Nauki i Obrazovania, 33(3), 117-123.

[14] Gilmanshina, S. I., Sagitova, R. N., Gilmanshin, I. R., \& Kamaleeva, A. R. (2017). Teaching of students' technology early professional orientation of schoolchildren. Paper presented at the IOP Conference Series: Materials Science and Engineering, 240(1) https://doi. org/10.1088/1757-899x/240/1/012023

[15] Goodlad, J. I. (1993). School-university partnerships and partner schools. Educational Policy, 7(1), 24-39. doi:10.1177/0895904893007001003

[16] Jakubowski, T. G., \& Leidner, D. (2007). The CSUN/LAUSD collaborative: A model University/School district partnership in the preparation of new school administrators https://doi.org/10.1016/s1479-3660(07)10004-4

[17] Komarova, E.P., Fetisov, A. S., Larina, T.V., \& Galustyan, O.V. (2017). The Development of Physical Training Culture of a Personality. Revista Espacios, Vol. 38(N 50). Retrieved from http://www.revistaespacios.com/a17v38n50/17385028.html

[18] Kravchenko E.V., Galustyan O.V, Kovtunenko L.V., \& Kolosova L.A. (2018). Pedagogical Practice of Students. Revista Espacios, Vol. 39 (N 17). Retrieved from http://www.revistaespacios.com/a18v39n17/18391731.html

[19] Larskikh, Z. P. (2016). The main trends for arranging project activities in practice of the modern elementary school. International Review of Management and Marketing, 6(3), 275-281. Retrieved from www.scopus.com

[20] Lutsik, V. I., Sobolev, A. E., \& Isaev, D. S. (2018). Regional educational projects as means of raising level of university entrants in chemistry. Izvestiya Vysshikh Uchebnykh Zavedenii, Seriya Khimiya i Khimicheskaya Tekhnologiya, 61(6), 103-108. https://doi.org/ $\underline{10.6060 / \text { tcct.20186106.5689 }}$

[21] Nurullina, G. M., Muraviyov, A. F., Martyanova, A. A., \& Yarmakeev, I. E. (2018). Project technology in the development of communicative competence in schoolchildren: Extracurricular classes of russian language. Cypriot Journal of Educational Sciences, 13(4), 461-468. https://doi.org/10.18844/cjes.v13i4.3897

[22] Polly, D., Heafner, T., Chapman, M., \& Spooner, M. (2014). Professional development schools and transformative partnerships. Professional development schools and transformative partnerships (pp. 1-363) https://doi.org/10.4018/978-1-4666-6367-1

[23] Quesenberry, A. C., Hamann, K., Sanden, S., Bates, A., \& Hartle, L. (2018). Examining the impact of a year-long University-School partnership. Action in Teacher Education, 40(3), 288-304. https://doi.org/10.1080/01626620.2018.1486752

[24] Smith, B. J., Potts-Datema, W., \& Nolte, A. E. (2005). Challenges in teacher preparation for school health education and promotion. Promotion \& Education, 12(3-4), 162-164. https://doi.org/10.1177/10253823050120030116

[25] Troeshestova, D. A. (2018). Olympiad movement in the system of partnership "schooluniversity-enterprise". Vysshee Obrazovanie v Rossii, 27(12), 116-125. https://doi.org/10. $\underline{31992 / 0869-3617-2018-27-12-116-125}$ 


\section{Authors}

Olga V. Galustyan is Professor of the Department of Education and Pedagogical Sciences, Academy of Psychology and Pedagogy of Southern Federal University, Rostov-on-Don, Russia.

Vladimir A. Kirik is Director of Academy of Psychology and Pedagogy of Southern Federal University, Rostov-on-Don, Russia.

Nataša Mazáčová is Associate Professor of Department of Pedagogy, Hussite Theological Faculty of Charles University, Prague, Czech Republic.

Article submitted 2019-05-08. Resubmitted 2019-07-23. Final acceptance 2019-07-24. Final version published as submitted by the authors. 